\title{
Project implementation success and Change Management practices in Malaysian Government-linked companies (GLCs)
}

\author{
*Saeed Salem Basamh, Md Najibul Huq, Abdul Rahman Ahmad Dahlan \\ International Islamic University Malaysia, Malaysia \\ *saeed.basamh@gmail.com
}

\begin{abstract}
The purpose of this research is to address the practices of project change management in the context of Government-Linked Companies (GLCs) in Malaysia, focusing on Project Managers (PMs), Project Team Members (PTMs), Change Managers (CMs) and any other Top Managers involved in a project. Also, checking the validity of a number of critical success factors from Project Implementation Profile (PIP) in the context of GLCs in Malaysia. PIP is a comprehensive managerial tool that was introduced by Pinto and Slevin. Later Belout and Gauvereau have enhanced and re-tested it in their study. Government-linked companies were previously government agencies or public enterprises established to provide services for social purposes. The Malaysian Government considers the importance of the Government-linked companies' (GLCs) role. Critical success factors (or CSFs) are the actions and processes that can be controlled or affected by management to achieve the goals set by an organization. Many studies has been conducted on Malaysian government-linked companies, but few focused on examining the validity of the critical success factors in these companies where these factors will lead to successful project implementation and assess in change management.
\end{abstract}

Keywords: Change management, Government-linked companies, Malaysia, Project implementation profile, Critical success factors

\section{Introductions and Literature Review}

The field of project management has developed and the need is arising as product life cycles flatten, desire for new technologies are increasing, and business takes on an increasingly global character. Change is an essential component of continuous improvements. Any improvement methodology involves introducing change and measuring its impact. Change Management is the process of planning and structuring to help align an organization with the change. In a simple and effective form, change management involves working with an organization's stakeholder groups to assist them in understanding what the change means for them, helping them make and sustain the shift and working to overcome any challenges involved. It involves the organizational and behavioral adjustments that need to be made to adapt and sustain change from a management perspective.

The constraints' triangle has set the standard for defining project success with scope, schedule, and the budget. Companies are now realizing that the traditional metrics do not reflect all important success criteria. The project's overall effect to the business, how effectively it solves the organizations' necessities and the general insight of the project are what define a true project success. A project to be considered successful needs suitable planning and the help from the management. Exceeding customer requirements will bring about success to the project. Understanding the business drivers and ensuring that the project meets the objectives of the business will also contribute to success. Project is an important key that affects the existence of an organization, moreover to create and maintain its competitive advantage in a market. The outcomes produced from projects will urge an organization to develop new goods, processes, and services in a better, cheaper and faster way (Bavec, 2009). Projects are also important in terms of satisfying customers' needs, and enhancing productivity and effectiveness.

Table1: Sources of Critical Success Factors (CSFs)

\begin{tabular}{lll}
\hline Element & Authors & No. Of Citations \\
\hline Communication & Asemi \& Jazi (2010), Nahar et al., (2006), Habib (2009), Yu et al., & 7 \\
& (2006), Laframboise, Nelson \& Schmaltz (2002), Chomsky & \\
& (2013), Slevin \& Pinto (1986). & \\
Top Management & Slevin\& Pinto (1986), Youssef \& Zairi (1995), Gartner group 5 \\
Support & (2004), Naher el al. (2006), Ogunlana (2009), Hussein et
\end{tabular}




$$
\text { al.,(2007). }
$$

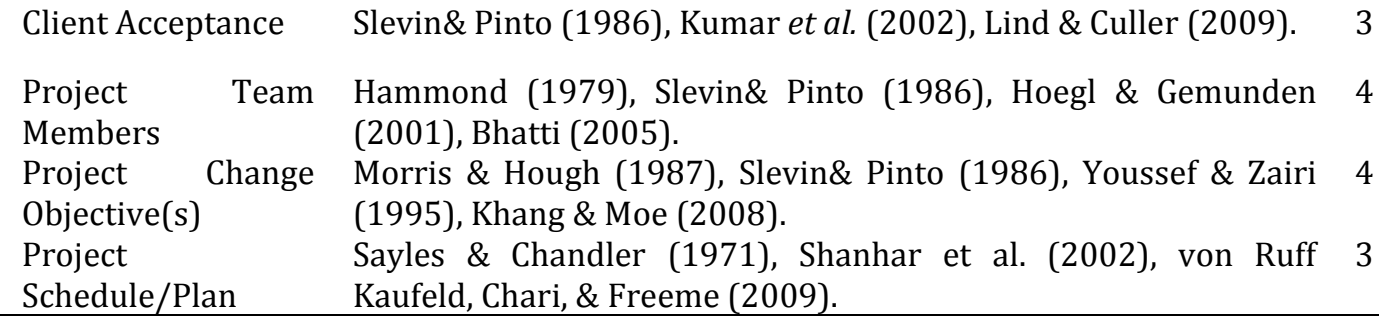

The Change Management: Change management is an approach that is structured to shift individuals, teams, and organizations from present state to a looked-for future state, to fulfill or implement a vision and strategy. An organizational process aims at allowing employees to accept and embrace changes in their existing environment. There are different streams for change management as an organized process, a means of shifting people, and as a competitive approach that have shaped the practice of change management. Change can be an opportunity for some and a threat and time loss to others. Change is an integral characteristic of any organization, any organization whether in the public or private sector must change to stay significant. When change introduced to an organization, it will affect one or more segments of how the organization operates. These segments are processes, systems, organization structure, or job roles. There are many approaches and tools that can be used to improve an organization; all of them prescribe adjustments to one or more of the four segments in an organization.

While the perception of becoming more competitive, becoming closer to the customer or becoming more efficient can be the motivation to change, at some point these goals must be transformed into specific impacts on processes, systems, organization structures or job roles. It is an assumption that endurance to change is a common and natural occurrence (Buchanan \& Huczynski, 1985). Inducting change is a competitive and hard activity (Lindblom, 1994). Major technological changes or innovations can allow for endurance, mostly when the proposed change affects values and visions related to existing order. Changes normally benefit some people by injuring others (Trader-Leigh, 2002).

The success of organizational change efforts has been addressed by number of success factors. These factors including senior management commitment, communicating objectives of change efforts, involving technical staff and operating managers in the change process, establishing a sense of urgency, focus on solving concrete business problems, effective measurement tools, theories and techniques, reorganizing employee roles, responsibilities and relationships to address the organization's new structure, to monitor and adjust the transition in response with change process issues, removing obstacles to the change process, and securing changes in the organization's culture (Belohlav, 1997). Change management in project management is a complicated structure. In change implementation, a concurrent manager must be able to respond to a variety of difficult aspects of the change (Graetz, 2000). Change managers are responsible for assessing the organization's capacity to change, defining a solid vision of the looked-for future, observing the current situation and repairing gaps, elaborating change strategy, executing the plan within the budget and finally observing the results. Sometimes, a change manger must manage at the intuitive level when there are too many or too few variables or facts available to take acknowledgeable decision (Higgins \& McAllaster, 2004).

\section{Government-Linked Companies (GLCs) Environment}

In Malaysia, government-linked companies (GLCs) are main suppliers of utilities (e.g. Telecom Malaysia), postal services (e.g. POS Malaysia), airlines, airports, public transport, water and sewerage, and banking and financial services (e.g. Malayan Banking Berhad and CIMB). Several GLCs also participate in the automotive, plantation, and construction industries. The group employed approximately Four-Hundred Thousands employees of the national workforce, and accounts for more than 30 percent of the Malaysian Stock Exchange market capitalization and 54 per cent of the Kuala Lumpur Composite Index. Considering the significance of GLCs to the economy, an understanding of the changes that this type of organization is going through is significant and, therefore, deserves intensive research (Norhayati \& Siti-Nabiha, 2009). GLCs are companies that have an essential commercial objective and the Malaysian government has direct control, which refers to the government's ability to designate Board of Directors (BOD) members, senior management, and make major decisions like; contract awards in addition to percentage ownership. The frontiers between the public and the private sectors are blurred and overlay in some 
areas. This overlay differs not just between countries, but also at a narrower level. Regardless of the increase in privatization and domestic markets, the public sector remains quite isolated from the private sector in many ways. Whereas there are financial controls and targets, the primary goal is not maximizing revenue (Khazanah National, 2013).

The role of Government-Linked Companies (GLCs) is considered important to the Malaysian Government. A significant part has been played by GLCs, to ensure that Malaysia will achieve its mission in becoming a developed nation by the year 2020. GLCs role is noticeable in utilities and services such as electricity, communication, airlines, airports, and banking and financial services sectors. Malaysian GLCs are fusion organizations, as they have to achieve financial returns while fulfilling their social responsibilities. GLCs were previously government agencies or public enterprises established to provide services for social purposes. Malaysia's privatization policy, introduced in the early 1980s, resulted from the objectives of the New Development Policy, a rising national debt as well as from the belief that the policy would drive the government agencies to become more efficient and cost effective (Syn, 2002).

The Critical Success Factors (CSFs): It is necessary for an organization or a project to achieve its mission by addressing an element that is described by the term Critical Success Factor (CSF). It is a critical action or factor, which is required to ensure the success of an organization or a company. The term is used initially in the world of business analysis and data analysis. For example, as found in many papers that user involvement in an Information Technology (IT) project is a critical success factor, which will lead to a successful project (Rocket, 1979).Critical Success Factor is the narrow numbers of areas in which results in ensuring a competitive performance for the organization, if they are satisfying (Fortune \& White 2006). CSFs are used to design information systems and this definition is rooted in the private sector. Critical success factors are the actions and processes that can be controlled or affected by management to achieve the goals set by an organization. They are crucial things that the company must achieve or in which areas will produce the greatest competitive edge (Bhatti, 2005). Project success is a significant management issue (Crawford, 2002), it is one of the most topics discussed and there is a disagreement about the criteria by which success is judged (Slevin\& Pinto, 1986). There are numbers of considerations on success factors only some of these factors are discussed. The project implementation profile, which is a comprehensive managerial tool consisting of most of the critical success factors as discussed in the framework section.

Research Questions and Objectives: In this attempt to conceptualize change management in the context of the Malaysian Government-Linked Companies (GLCs) the following questions will be undertaken: Are the Pinto's critical success factors valid in the context of the Malaysian Government-Linked Companies change management? If so which critical success factor(s) are the most important ones? To answer this research query, the study is open to gather any additional information related to the subject, where participants can add comments. This part is important because there are some relevant elements might have been captured in literature, while they might be very significant to the success in the GLCs change proposals. These comments might provide inspiration for future studies and to enrich this study. The objective behind finding answers to the research questions is to enrich the quantity and quality of valuable data on the subject of Government-linked companies change management will be achieved. The main objective can be abbreviated into pieces:

- Define the notion of change management in the Malaysian Government-Linked Companies environment.

- Inspect the validity of PIP by administering a survey to several project managers and project team members from a different government-linked company.

- Perform statistical procedure on the collected data to define the significance of the chosen success factors and the correlation between variables.

- Find the correlation between identified independent variables (Critical factors) and project success.

- $\quad$ Document any ideas and hypotheses collected from participants.

\section{Methodology}

The paper was conducted with a primary focus on the empirical study of a survey using a questionnaire formulated from the core success factors of Change Management as described by multiple Academic papers. The survey questionnaire will be distributed in both Electronic form and Paper form. The electronic version has been developed through Google Docs format, which would record the data in a 
spreadsheet for further analysis and statistical reporting. The distribution list and participants are predominantly Information Technology and Project Management professionals from different Government Linked companies in Malaysia. Experience in Project Management is key in contributing to the successful use of the Survey. The government-linked companies in Malaysia are important driving force for most of the new and innovative projects in Malaysia. The GLCs account for the majority of the critical projects in Malaysia, and is an important driving force for the economy. Therefore, we believe the information obtained will contribute to sufficient insight on change management practices and address the success factors for arguably the most important organizations of the country.

Conceptual Framework: There are many models regarding the change management step by step methods illustrated by (Lewin, 1951) a classical three-phase model of change [unfreeze, move or change, and refreeze](Kotter, 1995), popular eight-step change model, the McKinsey's 7-S model (McKinsey), and the ADKAR model (ProSci, 1998). In this study, the focus will be on some of the critical success factors, from Project Implementation Profile (PIP), which is a comprehensive managerial tool. Project Implementation Profile or PIP consists of 10 critical success factors. The model was based on the empirical studies performed by Pinto and other coauthors: Slevin, Prescott, Covin and Mantel (Belout \& Gauvereau, 2004). Pinto's research in 1986 and his consequent findings with Slevin on their findings of 10 critical success factors have become a piece of works.

Figure1: the proposed framework based on Project Implementation Profile (PIP) introduced by Pinto and Slevin

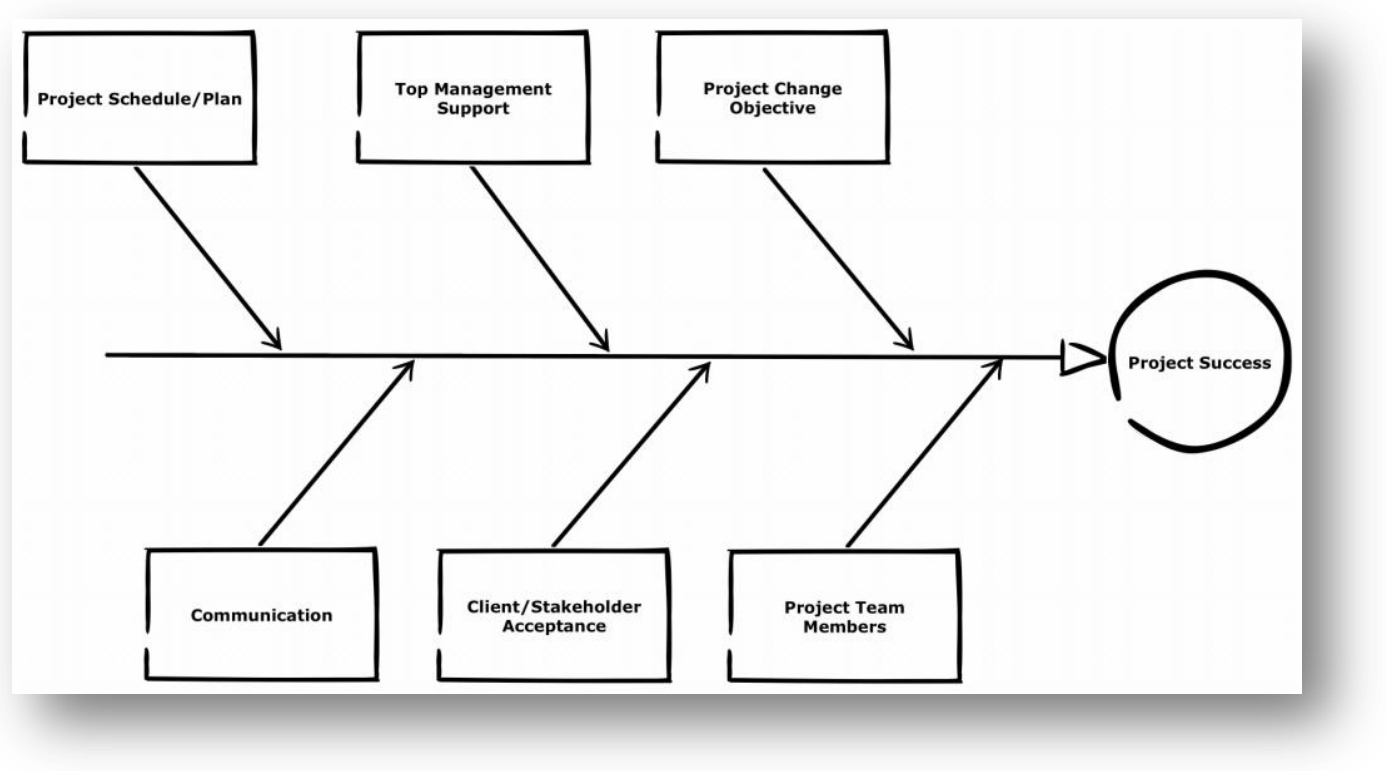

Their model is one of the most commonly cited lists of critical success factors (Turner \& Müller, 2005).To understand more about the framework, it was enhanced and re-tested by the study done by Belout and Gauvereau. They were interested in examining various sectors; however the public sector was not one of them. This study is concerned only with government-linked companies in Malaysia (GLCs). An examination and an adaptation to GLCs existence of each factor follow. The framework will focus on six independent success factors, to find out if they are associated with the success of the government-linked companies change management in Malaysia.

Communication: Both professionals and academics consider communication as a crucial success element alike. Wherever there is a failure of a change initiative, under-communication often exists. One-way communication will not avail; it is required to construct a two-way communication channel. Communication includes deeds and words and they all count. There is a strong connection between a feedback to the change, which is favorable and thorough communication (Chomsky, 2013). Within the organization, inner communication is an important factor contributing to project success (Laframboise $e t$ al., 2002).

Client(s) Acceptance: There are many stages in project management and client acceptance is one of them, also it has to be managed like the rest of the stages. Client satisfaction is a complex element in 
change management. The success of the project in terms of fulfilling its objectives is simpler to measure. Any key stakeholder involved in a project should be wearing the client's hat. The company as well as individual partners will face exposure, if it fails to take a selective approach to client acceptance. Client acceptance is an important factor in any project success (Peter, 2003).

Top Management Support: In the early stages of any project, there is no factor is so predictive of its success as the top management support. It is really important to call for management support. Authorizations, the willingness of top management to be involved and to give a certain amount of resources is the key to a successful implementation. The vital role played by top management to a successful implementation of any project including Information Technology in an organization (Aggarwal, 2010). It is important that change manager has to ensure that further managers and key stakeholders enthusiastically, tangibly, repeatedly are supporting change project and also aware of it. They all must provide support during crisis and they have to believe in success.

Project Team Members: The team is an important variable in the implementation process (Hammond, 1979). Building the right group of people for a particular project is not an easy task. Failure arises when selecting and training of the team is not given enough. Often project manager or involved manager makes the decision on who is going to join the team but change manager might not have control over higherclass choice. Change manager can choose the best people and provide established training for them. It is required to support of the group, however the support between team members to the rest of the group is vital (Jones et al., 2004).

Project Schedule/Plan: Any project even if it is well supported, will never succeed without a solid plan. All activities required defining and arranging and ample resources needed to be allocated. Besides, an essential way to measure the progress against the projection must be right (Slevin\& Pinto, 1986). A good and solid project plan is needed to support the initiative. In companies like the Malaysian GovernmentLinked Companies, any project has to be totally clear. Occasionally, new manager or change manager must be able to pick up where the last one has left because people are replaced over time. Without a proper (sound and good) plan, financing of resources will be far away from the target. A plan must be workable, realistic and satisfactorily matched with the available resources. It must be in line with a business plan and board recommendations.

Project Change Objective: Defining goals of the desired operation is an essential step in any project. The ultimate goal in the case of project management is the change. Project change is common in private sectors, but in the case of the Malaysian GLCs where they were public sectors and then they have been privatized as mentioned in the literature, project change is a novelty. Having an accurate, clear and specific change objective is required from the change manager. Others have to understand the objectives as necessary, for that they have to be comprehensible and tangible to be easily perceived.

Findings from Literature Review: People's capacity to change can be affected by how change is presented to them, which is the underlying basis of change management. Barriers and non-stop issues arises when they misunderstand and resist to change. If people understood the benefit of change, they will participate in change and will see it successfully carried out, which will lead to the slightest trouble to the organization. Many studies on the Malaysian government-linked companies those have addressed and remain addressing the economy and finance point of view. The Malaysian government has high expectations from these GLCs and their role to take the country and its people to a better future and to achieve their goals by 2020. However, not much of studies those address an important element to change, which will lead to successful projects and better in quality. It is found that many critical success factors has been introduced and tested in many private organizations in many countries with successful results and improvements to the organization and their stakeholders. Moreover, Pinto's framework concerns about the human factor in the change, as it is considered the key to any project success especially in IT projects.

\section{Conclusion}

The concept behind this paper is to address the change management practices in GLCs and how projects to be implemented successfully. Successful change is filled with surprises and complex. In order to be achieved, GLCs managers when residing with plans and processes must face difficult and critical human issues. CSFs are viewed under the lens of the soft side of change management (Aldhfayan, 2008). Inspired 
by the PIP framework, six success factors will be tested within the government-linked companies in Malaysia. The contribution of this paper is to find the correlation between independent and dependent variables, which will lead to a successful project implementation.

\section{References}

Aggarwal, H. (2010). Critical Success Factors in IT Alignment in Public Sector Petroleum Industry of India. Complexity, 21(21), 22.

Aldhfayan, F. (2008). Analysis on the role of standardized project management on project performance. $\begin{array}{llll}\text { Retrieved April } & 18, & 2013 & \text { from }\end{array}$ http://www.strategicstandards.com/files/2008/ProjectManagement08.pdf

Asemi, A. \& Jazi, M. D. (2010). A Comparative Study of Critical Success Factors (CSFs) in Implementation of ERP in Developed and Developing Countries. International Journal, 2(5), 99-110.

Bavec, C. (2009). On the creative climate and innovativeness at the country level. Proceedings of Rijeka Faculty of Economics. J. Econ. Bus, 27(1), 9-30.

Belohlav, J. A. (1997). Managing Transitions. Quality Progress, 30(4), 93-96.

Belout, A. \& Gauvreau, C. (2004). Factors influencing project success: the impact of human resource management. International journal of project management, 22(1), 1-11.

Bhatti, T. R. (2005, September). Critical success factors for the implementation of enterprise resource planning (ERP): empirical validation. In The Second International Conference on Innovation in Information Technology (p. 110).

Buchanan, D. A. \& Huczynski, A. (1985). Organizational behavior: an introductory text. Prentice-Hall International.

Chomsky, N. (2013). Some notes on economy of derivation and representation. Anuario del Seminario de FilologíaVasca Julio de Urquijo, 53-82.

Crawford, J. K. (2002). The strategic project office: A guide to improving organization performance.

Fortune, J. \& White, D. (2006). Framing of project critical success factors by a systems model. International Journal of Project Management, 24(1), 53-65.

Graetz, F. (2000). Strategic change leadership. Management decision, 38(8), 550-564.

Habib, Z. (2009). The Critical Success Factors in implementation of Software Process Improvement Efforts: CSFs, Motivators \& Obstacles. rapport nr: Report/Department of Applied Information Technology 2009: 056.

Hammond III, J. S. (1979).A practitioner-oriented framework for implementation. The Implementation of Management Science, 35-62.

Higgins, J. M. \& Mcallaster, C. (2004). If you want strategic change, don't forget to change your cultural artifacts. Journal of Change Management, 4(1), 63-73.

Hussein, R., Abdul Karim, N. S., Mohamed, N. \& Ahlan, A. R. (2007). The influence of organizational factors on information systems success in e-government agencies in Malaysia. The Electronic Journal of Information Systems in Developing Countries, 29(2).

Jones, J., Aguirre, D. \& Calderone, M. (2004). 10 Principles of Change Management. Strategy+ Business, 1-5.

Khang, D. B. \& Moe, T. L. (2008). Success criteria and factors for international development projects: A life-cycle-based framework. Project Management Journal, 39(1), 72-84.

Khazanah National. (2013). Frequently asked questions. Retrieved April 18, 2013from http://www.khazanah.com.my/faq.htm

Kotter, J. P. (1995). Leading change: Why transformation efforts fail. Harvard business review, 73(2), 5967.

Kumar, V., Maheshwari, B. \& Kumar, U. (2002). ERP systems implementation: best practices in Canadian government organizations. Government Information Quarterly, 19(2), 147-172.

Laframboise, D., Nelson, R. L. \& Schmaltz, J. (2002). Managing resistance to change in workplace accommodation projects. Journal of Facilities Management, 1(4), 306-321.

Lewin, K. (1951). Field theory in social science. Harper \& Row, New York.

Lind, M. R. \& Culler, E. The Relationship between Information Technology Critical Success Factors and Project Performance. In The Proceedings of the Conference on Information Systems Applied Research 2009, v 2 (Washington DC): §2362. ISSN: 0000-0000.

Lindblom, C. K. (1994, April).The implications of organizational legitimacy for corporate social performance and disclosure. In Critical perspectives on accounting conference, New York. 
Nahar, N., Lyytinen, K., Huda, N. \& Muravyov, S. V. (2006). Success factors for information technology supported international technology transfer: Finding expert consensus. Information \& management, 43(5), 663-677.

Norhayati, M. A. \& Siti-Nabiha, A. K. (2009). A case study of the performance management system in a Malaysian government linked company. Journal of Accounting \& Organizational Change, 5(2), 243-276.

Ogunlana, S. O. (2009). Construction professionals' perception of critical success factors for large-scale construction projects. Construction Innovation: Information, Process, Management, 9(2), 149-167.

Peter, F. (2003). Applying the Slevin-Pinto project implementation profile to an information systems project. Project Management Journal, 34(3), 32.

ProSci. (1998). Best Practices in Managing Change. Retrieved April 15, 2013 from http://www.prosci.com.

Rockart, J. F. (1979). Chief executives define their own data needs. Harvard business review, 57(2), 81.

Slevin, D. P. \& Pinto, J. K. (1986). The project implementation profile: new tool for project managers. Project Management Journal, 17(4), 57-70.

Syn, T. W. (2002). Centre on Regulation and Competition.

Trader-Leigh, K. E. (2002). Case study: identifying resistance in managing change. Journal of Organizational Change Management, 15(2), 138-155.

Turner, J. R. \& Müller, R. (2005). The project manager's leadership style as a success factor on projects: a literature review. Project management journal, 36(2), 49-61.

vonUrffKaufeld, N., Chari, V. \& Freeme, D. (2009). Critical Success Factors for Effective IT Leadership. In Proceedings of the 2nd European Conference on Information Management and Evaluation (p. 433). Academic Conferences Limited.

Yu, A. T., Shen, Q., Kelly, J. \& Hunter, K. (2006). Investigation of critical success factors in construction project briefing by way of content analysis. Journal of Construction Engineering and management, 132(11), 1178-1186. 